\title{
Technè
}

La science au service de l'histoire de l'art et de la préservation des biens culturels

44 | 2016

Archives de l'humanité : les restes humains patrimonialisés

\section{Bog bodies: the Grauballe Man}

Les corps des tourbières : l'homme de Grauballe

\section{Pauline Asingh and Niels Lynnerup}

\section{(2) OpenEdition}

1 Journals

\section{Electronic version}

URL: http://journals.openedition.org/techne/1134

DOI: 10.4000/techne. 1134

ISSN: 2534-5168

\section{Publisher}

C2RMF

\section{Printed version}

Date of publication: 1 November 2016

Number of pages: $84-89$

ISBN: 978-2-7118-6339-6

ISSN: $1254-7867$

\section{Electronic reference}

Pauline Asingh and Niels Lynnerup, « Bog bodies: the Grauballe Man », Technè [Online], 44 | 2016,

Online since 19 December 2019, connection on 10 December 2020. URL : http://

journals.openedition.org/techne/1134; DOI : https://doi.org/10.4000/techne.1134

\section{(c) $\oplus \Theta \Theta$}

La revue Technè. La science au service de l'histoire de l'art et de la préservation des biens culturels est mise à disposition selon les termes de la Licence Creative Commons Attribution - Pas d'Utilisation Commerciale - Pas de Modification 4.0 International. 


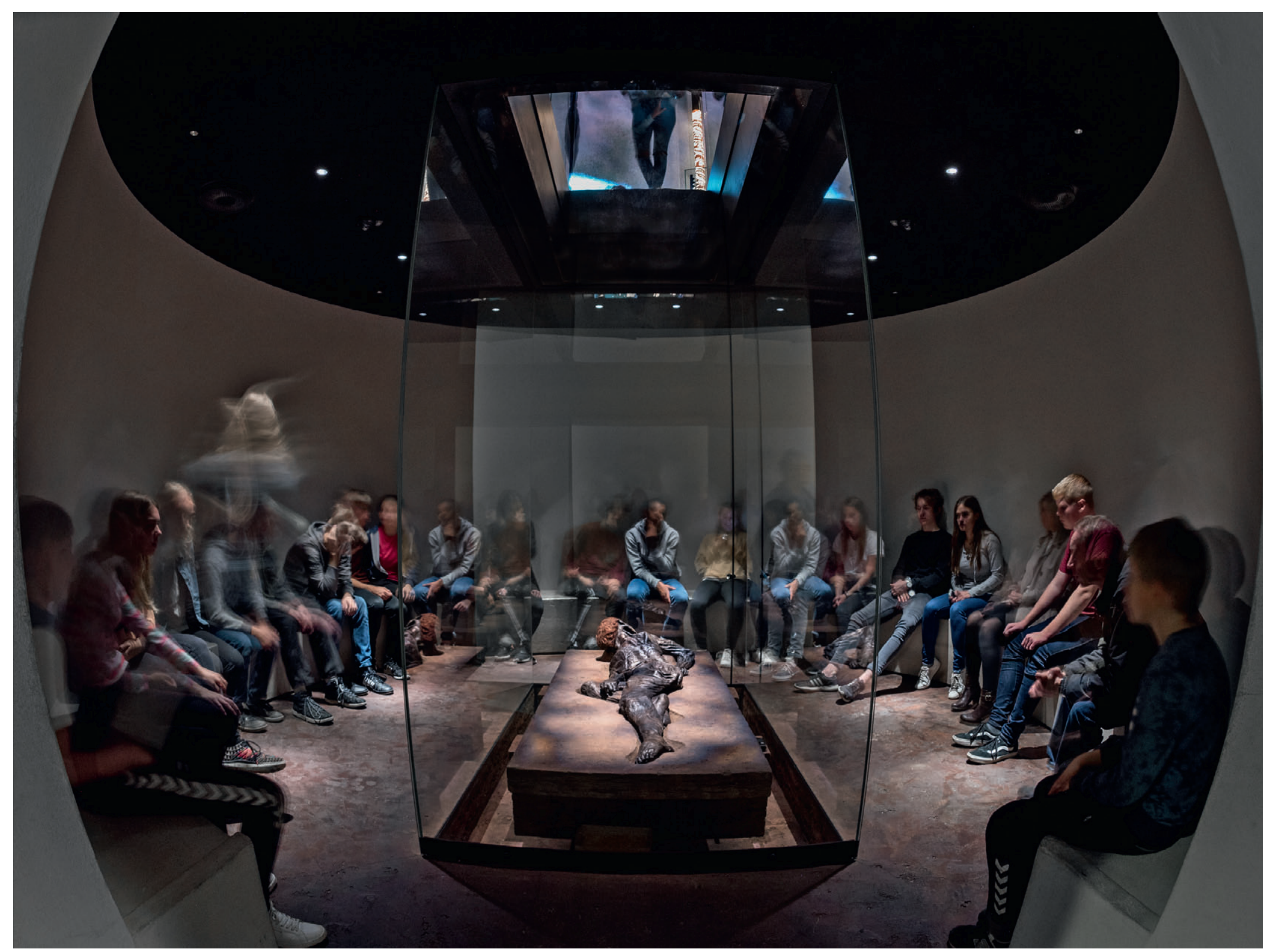

Fig. 1. Exhibition: Grauballe Man on display at Moesgaard Museum. (c) Medie dep. Moesgaard/S. Christensen. 
Pauline Asingh

Niels Lynnerup

\section{Bog bodies : the Grauballe Man}

Les corps des tourbières : l'homme de Grauballe

Abstract. The discovery of the well-preserved bog body: "Grauballe Man" was a worldwide sensation when excavated in 1952.

Grauballe Man was exhibited to the public, still drenched with bog water and resting on the block of peat only a few days after his discovery. At the time, several scientific investigations were carried out, and Grauballe Man has since been on exhibit at the Moesgaard Museum, Aarhus, Denmark. Recently, new scientific investigations were carried out, revealing much new data.

This kind of find, however, also raises many questions regarding conservation efforts, exhibition and the ethics of putting human remains on display.

Keywords. Bog bodies, human remains, exhibit, conservation, scientific analyses.
Résumé. La découverte de l'homme de Grauballe, un corps des tourbières remarquablement conservé, a suscité une vive émotion dans le monde entier en 1952. Le public a pu voir l'homme de Grauballe encore couvert de boue posé sur son bloc de tourbe, quelques jours seulement après sa mise au jour. Les scientifiques de l'époque ont conduit des recherches et l'homme de Grauballe est désormais exposé au musée Moesgård, à Aarhus. Des travaux récents ont fourni de nouvelles informations. Ce type de découverte soulève toutefois de nombreuses questions éthiques concernant la restauration et l'exposition des restes humains.

Mots-clés. Corps des tourbières, restes humains, exposition, restauration, analyses scientifiques.

Few discoveries from Denmark's prehistory enjoy the attention afforded by the public and the media to Grauballe Man, the well-preserved Iron Age bog body exhibited at Moesgaard Museum, south of Aarhus.

The museum's director, Professor P.V. Glob, saw the discovery of this well-preserved bog body as a worldwide sensation when excavated in 1952. The man from the bog represented our distant ancestors and also appeared to have been an unusually handsome and stately young man. With references to the Greek Nerthus cult, he was seen as a fertility sacrifice. The Bishop of Aarhus gave his blessing, and a series of investigations of the bog body was planned to take a close look at the lives of Iron Age people - X-radiology, an autopsy and investigations of his gut contents, teeth, etc. It was also crucial to preserve this dignified representative of our ancestors for posterity, i.e. conserve his body for the future and for exhibition to the public. From the first moment, Glob clearly considered him as both a scientific object and a precious museum exhibit. This was not a view seen previously in the treatment of bog bodies, several of which had simply wasted away in museum stores or been reburied in a bog or in consecrated ground in a churchyard. Only a few days after his discovery, Grauballe Man was exhibited to the public, still drenched

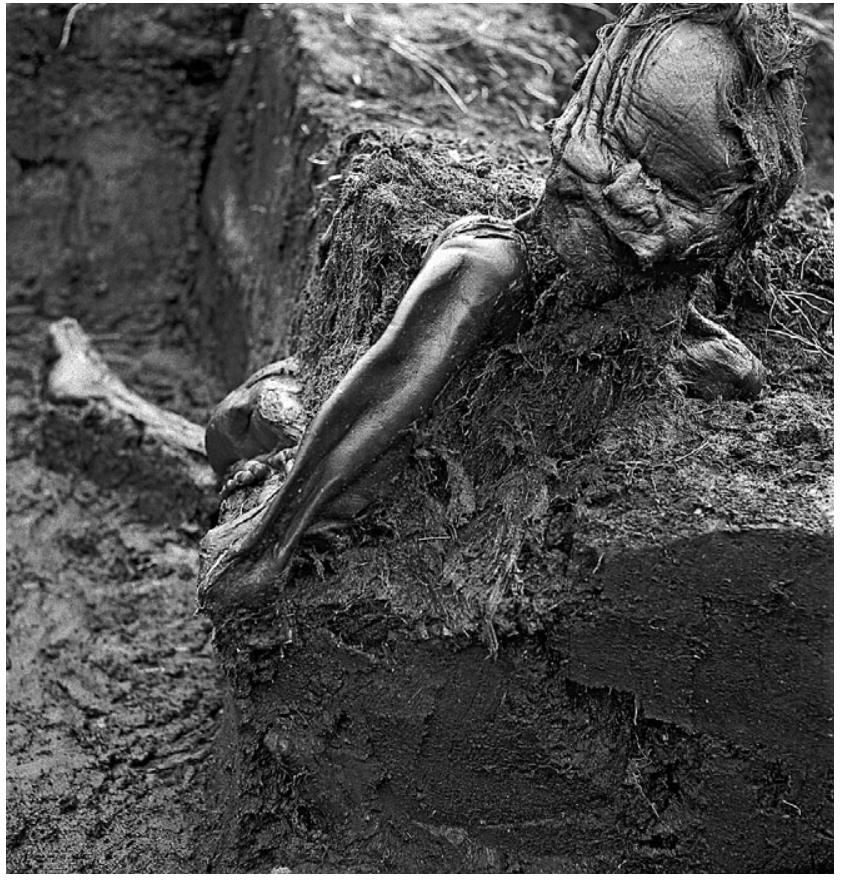

Fig. 2. Grauballe Man on findspot: the man in the bog, 27th april 1952. () Moesgaard Museum.

Pauline Asingh, curator, head of exhibition department Moesgaard Museum, Denmark (pa@moesgaardmuseum.dk). Niels Lynnerup Professor, Head of Unit, Laboratory of Biological Anthropology, Institute of Forensic Medicine, University of Copenhagen (nly@sund.ku.dk). 


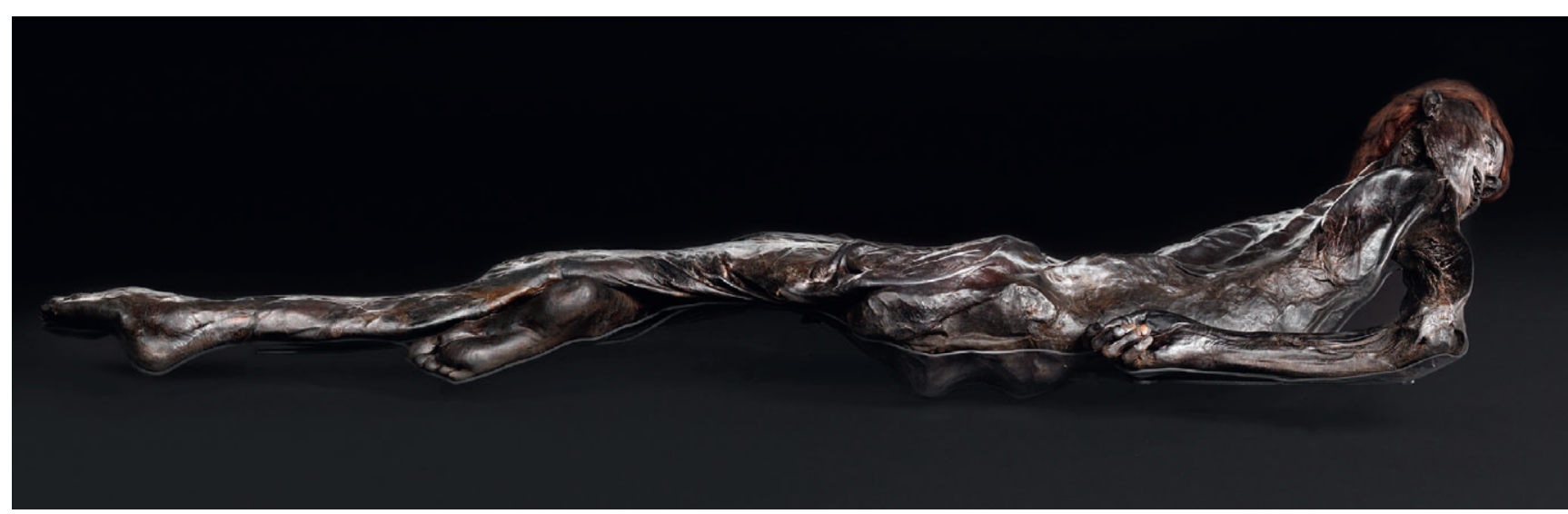

Fig. 3. Grauballe Man was laid in the bog just as naked as he came into the world. (C) Medie dep. Moesgaard/R. N. Johansen.

with bog water and resting on the block of peat in which he was carried to the museum. Everyone had to have a chance to see him before conservation and investigation began. The exhibition was a huge success and 18000 visitors passed his display case during the ten days he was on show. The world press wrote in astonishment about Danes flocking to see a dead Iron Age man in a glass coffin. People's behaviour at his display case was marked by dignity and respect, and many bared their heads, took off their hats, as they approached this great treasure.

\section{Conservation - an artificial bog}

Out of consideration for Grauballe Man's preservation, the exhibition had to close before guests became tired of looking at him. There then followed a busy programme of investigations before the conservator could begin the job of his life. Never before had an entire human body been conserved, so

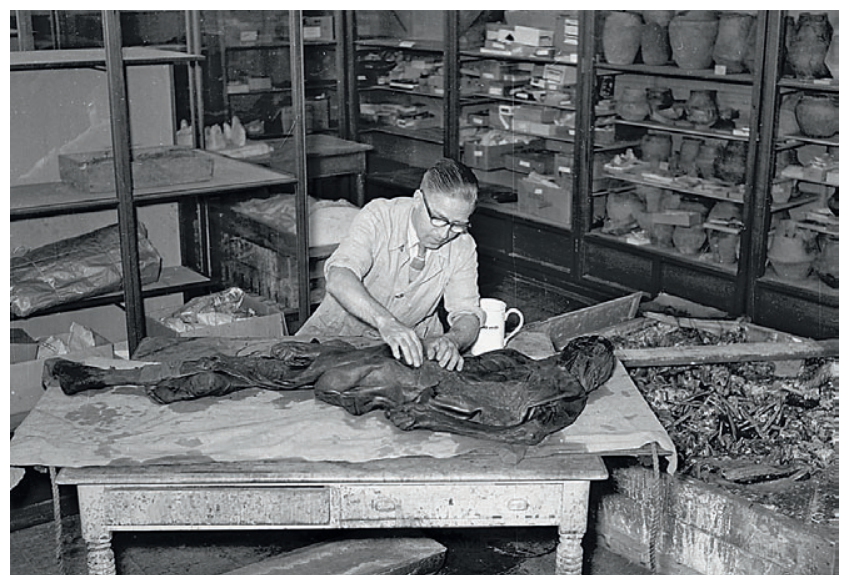

Fig. 4. The conservator preparing the body after conservation: the rubbing in leather dressing completed the conservation. (C) B. Venge/A. Stiftstidende. the first step was to invent a method. It was decided to complete the conservation process that had begun in the bog through more than two millennia. Eighteen months immersed in a bath of water and oak bark completed the tanning process and, as the conservator put it, Grauballe Man was then as well-preserved as an old boot. The conservation method was well-chosen, and the museum's conservators have established that he remains in an extremely stable condition today. His only treatment since conservation has been the regular application of Turkish Red Oil - similarly a very stable product.

\section{Preservation}

The first experimental scientific investigations of bog bodies, especially focusing on their preservation in the bog, had been performed by a Danish forensic pathologist, in 1913. He showed that peat could tan the skin, and that sphagnum acid was an important element in process. Furthermore, as with all post-mortem, diagenetic changes, low temperature plays an important role and bogs are also characterized by their acidity and absence of aerobic (putrefying) bacteria. Recent research has also shown that the diagenetic processes in the bog also rely on reactions involving a polysaccharide, sphagnan. Sphagnan also starts a process called the Maillard reaction: a complex suite of reactions between free aminogroups (amins, aminoacids, peptides and proteins) with reducing sugars. Maillard reactions are commonly encounted in foodprocessing, e.g. baking, where aminogroups combine with sugars (starch) resulting in "browning" of the foodstuffs. The end result of the above reactions, as seen for most bog bodies, is that bone mineral is leached from the mineralised tissues, and conversely that mineral salts, often containing iron, are probably absorbed into collagenous tissues such as the dermis, ligaments, tendons and fasciae.

Another important end result of the long stay in the peat bog is that the bog bodies become waterlogged. Presumably the tissues with their proteinaceous content draw water. It seems 
that the water content to some degree keeps the bog bodies in a more or less unaltered gross morphological shape and size, but when a bog body is dried out when taken from the bog the water evaporates, and this may lead to a marked shrinkage. The skull and facial skeleton will also be soft, meaning that impressions may be made if the find is not handled with care. The only way of preserving the bog bodies found before the Second World war was simply drying the body or body parts, out. The remains then stiffen in whatever position they were found in/laid out to dry. The tissues harden and the consistency of the bog body becomes like one of hardened cardboard. The body is no longer pliable and all folds and wrinkles will be set. All the above reactions will have grossly altered the tissues, and even more problematically, to a differing degree within even the single tissue type or tissue entity, like a within a single bone. Unfortunately, this may also lead to claims of extremely rare diseases or congenital disease, e.g. when some limbs are more shrunk then others. Grauballe Man changed this: as noted above his preservation was done by using oils, and thinking more closely about the boggy environment from which he came.

\section{In the spotlight of science}

Whatever their preservational condition, the bog bodies are of great interest for the natural and medical sciences. Not least the preservation of soft tissue allows for interesting analyses. As the skin is very often preserved in bog bodies, trauma, in the form of penetrating lesions or cuts, may be seen as well as minor pathologies such as warts, for which we have no other paleopathological sources or finds. Interior organs and muscles may also be preserved to differing degrees allowing assessment of these. At the same time, the presence of the integumentary soft tissue may hinder other analyses, not least osteological analyses. It is possible to conduct an autopsy, but while this has indeed been carried out, e.g. when the Grauballe Man was found, most scientists are not too keen on this procedure. An autopsy with full opening of the body cavities will invariably destroy the integrity of the bog body as an archaeological specimen, and future studies may be compromised. Today there is a recognition that a bog body is an invaluable archaeological object.

This makes X-raying and CT-scanning the methods of choice among the newer investigative techniques used on bog bodies. CT-scanning results in digital data which can be postprocessed, even down to manual editing of the single image slices. The 3-dimensional rendering also makes it possible to apply methods developed for dry bones for sexing and aging. Skull and pelvis shape may also be extracted and studied for sexing purposes. While external genitalia may be present on bog bodies, many bog finds comprise only body parts, and thus sexing will rely on extracting and assessing skeletal features or measures.

Based on the collective evidence by CT-scanning bog bodies, we contend that several, if not most previously described bog body trauma is post-mortem, the effects of

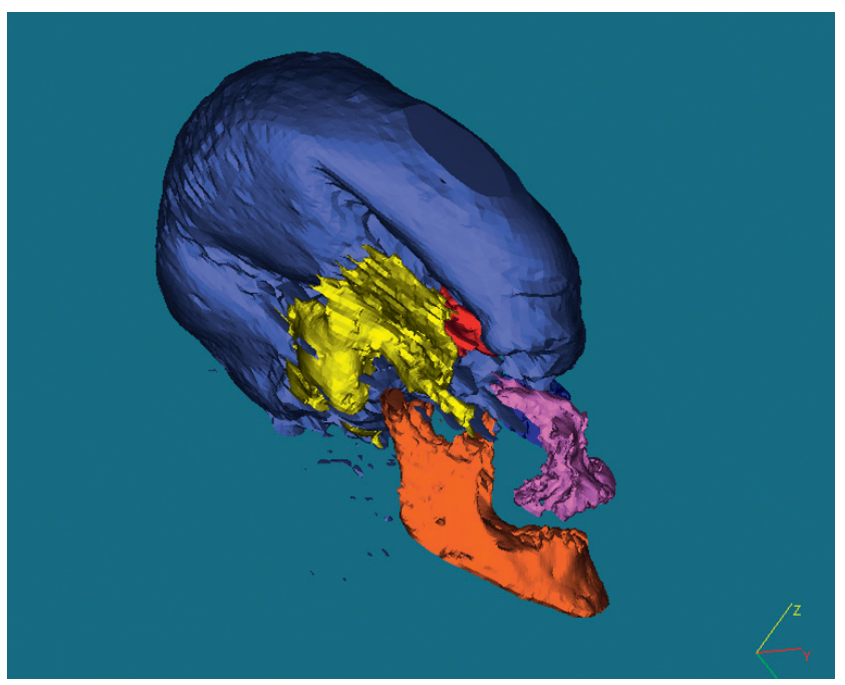

Fig. 5. 3D of skull: the CT-scan refutes previous claims of a fractured skull. () N. Lynnerup.

diagenesis, rather than peri-mortal and a result of deliberate violence. We acknowledge that this will probably be an ongoing discussion: the lesions, peri- or post-mortem, are all affected and changed diagenetically, blurring the distinctions even more, but certainly all lesions and signs of trauma should be appraised critically.

One additional benefit of CT-scanning is that the examination implicitly documents the bog body throughout. As CT-scanning is digitial, this also means that data can be shared with other scientists or museums, and easily stored for future reference. This may be of importance also for the curatorial staff, as a status of the preservation of internal structures may be had and used for references for the curatorial and preservational measures taken. Finally, the digital CT-scanning data may be used in 3-dimensional printing: it is possible to produce a 1:1 copy of scanned structures, e.g. a skull, with high resolution. This may be utilized for exhibitions purposes and as basis for facial approximations of bog bodies, e.g. Grauballe Man.

\section{The last meal}

As the gut contents may be preserved, bog bodies may provide a unique angle on diet reconstruction. Groundbreaking analyses of the gut contents of Grauballe Man were carried out when he was found, and a major re-analyses of the latter was carried out in 2007. Stomach and gut contents thus dramatically show what was the last meal. In the case of the Grauballe Man, this was mostly weed seed, with some grain and meat. 


\section{The hunt for DNA}

A final methodology deserves to be mentioned, as it invariably crops up when discussing bog bodies and their preservation; namely the possibility of DNA-analyses. A DNA analysis was attempted for the Grauballe Man, but, as expected to some degree, no DNA was recoverable (from dentine). The reason is most probably the acid, wet environment of the bog, which is detrimental to preservation of DNA-molecules. However, with the advent of techniques which allow detection of very short DNA-chains, this may change and perhaps a DNA results may be possible from bog bodies in the future.

\section{“Overkill” of overkill}

Not only do the more recent anthropological re-analyses not fully support the ideas of "overkill", but they also indicate that the bog body individuals were not physically different from the main Iron Age population. For example, it was speculated that the fingers of the Grauballe Man indicated that he was of noble birth, as an Iron Age man would be expected to have hands showing the effects of years of manual labour. This is more the result of the degenerative processes in the bog which results in the desquamation of the outer epidermal layer. Thus it cannot be conclusively stated whether the bog bodies overall represent younger, and perhaps therefore specially selected, individuals than the Iron Age background population.

\section{Grauballe Man on display}

Thanks to the scientific investigations carried out both back then and again recently, we now know a great deal about Grauballe Man's Iron Age life, so visitors to his display case can understand and identify with him. In Moesgaard Museum's new exhibition building, which opened in 2014, Grauballe Man has been given his very own department. In the lofty exhibition gallery, visitors walk out on the soft, pleasantly springy surface of the bog. Here they see exhibited the bog offerings and sacrifices from Grauballe Man's time, the Early Iron Age, 500-1 BC. Atmospheric scenography sets the scene, and visitors activate animations of votive ceremonies - a girl takes part in her family's sacrifice of dogs, a woman offers her long plait, father and son lower swords and white quartz stones into the water after victory in battle. Here, the museum presents its interpretations of these events and activities. Using fiction, they have wrestled with the archaeological facts to forge and promote identification with the people of the past. Out on the bog, an understanding emerges of how, in preChristian times, there was a completely different set of ethics and morals and other rules and laws than those we know today. Back then, it was common to make offerings and sacrifices to the gods and spirits who were known to have an influence on people and animals here on earth. The taking of a life to ensure fertility and life in the future provoked no feelings of guilt. And we see this as the fate of Grauballe Man, and of the other bog bodies, for that matter.

In the middle of the bog, visitors can look down on Grauballe Man, exhibited on the floor below. A direct view down through the display case to his body, resting on a base of coloured concrete; an abstraction of the structure and colour of the peat bog. From the bog, visitors descend to the floor below and enter Grauballe Man's room. This is circular and has a simple bench emerging organically from the walls all the way round. The floor holds the peat of the bog and the room exudes respect, dignity and intimacy. They are now in the bog where Grauballe Man has rested for more than 2000 years and, although other people are in the room, have a sense of being alone with him. Even when a group of schoolchildren is sat around the display case, voices become lowered, they are filled with wonder and respect, and so many questions. Curiosity far outweighs the horror, if that is at all an issue. Next door is Grauballe Man's cinema, where a docudrama is shown telling the story of his discovery, the media's treatment of it and the ethical questions at that time.

Fig. 6. Face reconstruction: Caroline Wilkinson during the development of the Iron Age man behind the bog body. (c) Moesgaard Museum/J. Kirkeby. 


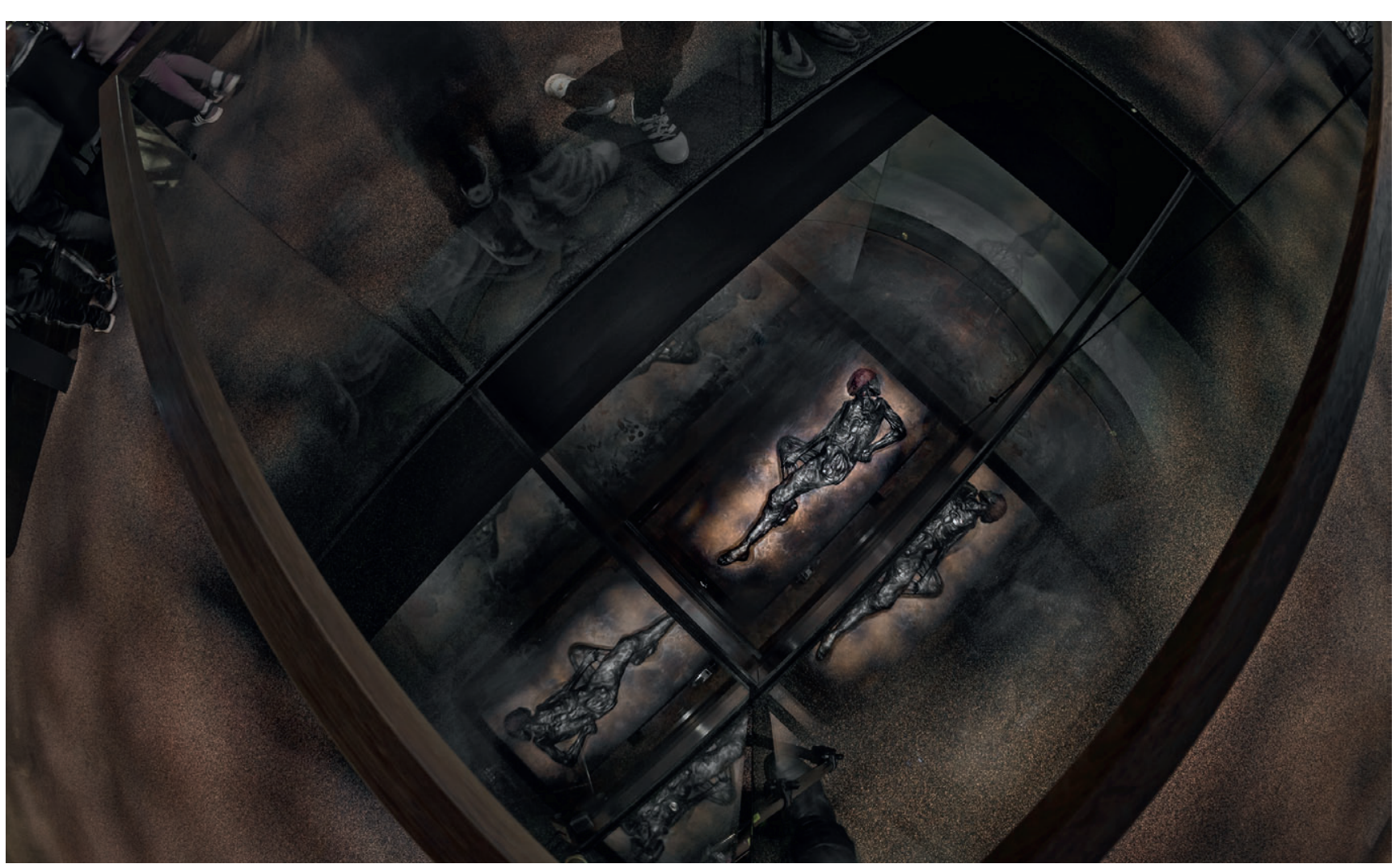

Fig. 7. The bog room in Moesgaard Museum: animations brings life to the sacrifices in the bog. In the middle, a look down to Grauballe Man. (c) Medie dep. Moesgaard/I. Kuriata.

It also deals with his conservation, the investigations carried out in 1952 and 2001 and their interpretation. So the film deals with both Grauballe Man's Iron Age life and death and his recent cultural history. The room is fitted out like the museum rooms of the time when Grauballe Man was found and investigated scientifically for the first time. It represents a time warp and presents the objects and artefacts associated with the bog body's recent cultural history in the 1950s, as well as having modern touch screens, where researchers associated with the programme of investigations present the results of their research. Both Grauballe Man and his cinema are very popular with museum visitors from both Denmark and abroad. The process-oriented presentation, whereby visitors follow the scientific research, from questions through processes to answers, is engaging and relevant. The museum hears no critical voices of an ethical nature about how appropriate it is to exhibit Grauballe Man - quite the contrary!

\section{Bibliography}

Asingh, P., 2009, Grauballe Man. A portrait of a bog body, Moesgaard Museum, Gyldendal, Copenhagen.

Asingh P., Lynnerup N., 2007, Grauballe Man, Århus University Press, Århus, p. 351.

Lynnerup N., 2012, "Mummies and Bog Bodies", The Global History of Paleopathology (Buikstra J, Roberts C, eds.), Oxford University Press, Oxford, U.K, p. 632-651.
Lynnerup N., 2010, "Medical Imaging of Mummies and Bog Bodies", Gerontology, 56(5), p. 441-448.

Lynnerup N., 2008, “Computed Tomography Scanning and Three-Dimensional

Visualization of Mummies and Bog Bodies", Advances in Human Paleopathology (Pinhasi R \& Mays S, eds.), John Wiley \& Sons Ltd, Chichester, p. 101-120.

Lynnerup N., 2007, Mummies, Yearbook of Physical Anthropology, 50, p. 162-190.
Melton N., Montgomery J., Knüsel C.J., et alii., 2010, "Gristhorpe Man: an Early Bronze Age log-coffin burial scientifically defined", Antiquity, 84, p. 796-815.

Price T. D., Frei K. M., Dobat A. S., Lynnerup N., Bennike P., 2011, "Who was in Harold Bluetooth's army? Strontium isotope investigation of the cemetery at the Viking Age fortress at Trelleborg, Denmark", Antiquity, 85(328), p. 476489. 